\title{
1. The shaping of the thought of the party governing politics and law in organizational history (1949-1958)*
}

\section{Liu Zhong}

At the end of the Qing Era and the dawn of the Republican Era, the emergence of political parties became the distinguishing feature of Chinese politics. Set apart from gangs, clans, sects, companies, and academic societies, parties integrated politics via stronger organizational capacity. ${ }^{1}$ As Liang Qichao observed, 'It is said, for those of the world, political parties are the world; for those of the country, political parties are the country'; 'in the civilized countries, one might hear of a party without country, but no one has heard of country without a party'; 'the world cannot go a day without politics, and hence, it cannot go a day without parties.' ${ }^{3}$

Leninist parties, through unmatched organizational capacity and unifying power, clearly stood out in the multiple-party context of Republican China. Hu Shi, China's 'Father of Liberalism,' lectured in England and the United States during 1926-1927, telling audiences that the modern science and civilization that Western countries brought to China were superficial, rather than substantive in content. In his view, it was not until the Soviet Russia’s Communist Party brought their Russian-style

* This chapter was produced as part of the Fudan University project for building 'Research on the National Judicial System, Judicial Philosophy, and Judicial Skill,' No. 985, Part 3. It was translated by Jonathan Kinkel, PhD candidate, Texas University at Austin.

1 See Lu Fangshang, The Return of Revolution: Responses of China to New Thought Before the Guomindang (1914-1924), the 'Central Research Institute' Recent History Research Office, 1989; Xie Bin, Republican Political Party History, Literature Star Bookstore, 1962.

2 'Political Party Talk,' Just Comment, Issue 78, published in the 27 th year of Emperor Guangxu's reign (21 March 1901).

'Avoiding the Establishment of Big Political Parties Will Not Save a Dying China,' Just Comment, Issue 79, published in the 27th year of Emperor Guangxu's reign (1 April 1901). 
political party organizational skills to China that Chinese people studied something truly tangible. ${ }^{4}$ In 1939, Mao Zedong said, 'Eighteen years of experience have taught us that the United Front, armed struggle, and Party construction are the Chinese Communist Party's (CCP) three keys for defeating our enemies.' ${ }^{5}$ Party construction involved both thought construction and organizational construction, and in 1942, to endure the structural problems of 'insufficient spirit unity, marching out of step, and each going one's own way,' the CCP Central Committee decided that the Party Committee would implement unified organizational leadership over Party, government, military, civil, and academic affairs. ${ }^{6}$

Regarding unified leadership, Japan's Defense Ministry summarized after the conclusion of World War II that military success in China during the war was actually contingent upon non-military strength. The execution of total war requires completely coordinated organizations that include the entire citizenry. The special characteristics of CCP organization are that the Party, government, and military are unified, that the military and the government are the two arms of the Party, and that the Party advances the revolution by operating these two arms while at the same time remaining strong in non-military areas such as political work, economic work, and social tide of thought. These characteristics form a giant military, political, and civic organizational apparatus that extends from the Center to the grassroots and takes the Party, possessing formidable unified strength, as the core - completely capable of adapting to the demands of total war. ${ }^{7}$

The style of 'Centralized Leadership of the Party Committee' in the environment of war served as part of the experience of the revolutionary party's successful rise to power, and it also boosted the consolidation of Party authority in post-war peacetime following the country's establishment. For example, Peng Zhen said, 'At every level of the police, procuracy, and court apparatus, unified leadership stems from Party Committees at every level.

4 See Luo Zhitian, The Troubled World Beneath: Nationalism and Republican Politics, Shanghai Rare Books Publishing House, 2001, pp. 235-237.

5 Mao Zedong, 'Foreword,' Communist Party Members, Issue 1 (1939), p. 5.

6 See 'The CCP Central Committee Decision Regarding Unified Resistance of Japanese Occupation According to Local Party Leadership and Adjustment of Organizational Relations,' 1 September 1942, Selected Works of Wang Jiaxiang, People's Publishing House, 1989, pp.328-339. This Decision was made by the Central Military Committee Chairman and Politburo Chairman Wang Jiaxiang as a CCP Central Committee draft and passed by the Central Politburo.

7 See Japan National Security Department War History Office (ed.), The North China Public Security War (Part 2), translated by the Tianjin Translation and Editing Group, Tianjin Publishing House, 1982, pp. 83, 462. 
This unity, in our long experience, has proved to be good. ${ }^{9}$ One of the two layers of the 'Party Committee Unified Leadership' ideology is in taking affairs such as finance, politics and law, culture, education, and health, labor unions, Youth League, and Women's League, and channeling them within the scope of the Party Committee's unified leadership. Among these, the Party Committee's leadership regarding political-legal institutions such as the police, procuracy, and courts has been emphasized in Central Committee policy decisions of recent years and rhetorically simplified as 'Party Governing Politics and Law.' Together with 'Party Governing

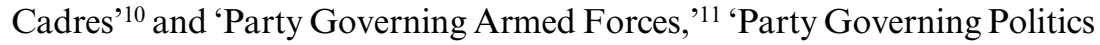
and Law' is included among contemporary China's most important administrative principles. In unique fashion, starting from the lack of permanent organizations during the transition period during and following the war, 'Party Governing Politics and Law' was gradually institutionalized into the interim style of the first period of the Political Consultative Committee, and then into the formal, internal Party structures established during the first ten years following the founding of the country in 1949.

This chapter narrates from historical facts the step-by-step formation of the 'Party Governing Politics and Law' ideology between 1949 and 1958, explaining how it represented a distinct structure, how it clarified the primary litigation structures, and what political administrative considerations were contained in this organization's evolutionary history. Given the streamlining of litigation and the central ideological concepts of police investigation, 'Party Governing Politics and Law' was primarily manifested as 'Party Governing Public Security,' showing no lack of an internal party structure coordinating every political-legal affair. After separating the different functions of investigation, arrest, preliminary hearing, complaint, judgment, enforcement, and judicial administrative affairs, the unified leadership ideology of the war period and the

8 Peng Zhen, 'Several Issues Regarding Socialist Legal Systems,' speech at the Central Party School, September1, 1979 (summary), Red Flag, Issue 11, 1979, p. 5.

9 See 'CCP Central Committee Opinion Regarding Strengthening and Improving Party Leadership of Politics and Law' (CCP Central Committee Doc. No. 15 [2005]); Zhou Yongkang, 'Hold High the Great Flag of Socialism with Chinese Characteristics, Diligently Initiate a New Era of Political Legal Work,' 24 December 2007, Selected Important Documents Since the 17th Party Congress (Part 1), CCP Central Committee Documents Selection Publishing House, 2009, pp.131-132.

10 See PRC Civil Servants' Law, Article 4.

11 See CCP Central Committee, the State Council, and the Central Military Commission's 'Opinion Regarding Strengthening and Improving Urban Militia Work,' 8 November 2002. 
organizational design experience of the Headquarters of the Front Line in Chief were used in the politics and law arena, establishing a structure for the overall planning and coordination of every function of politics and law. In this process of institutional formation, the CCP Central Committee continuously made adjustments based on the various political factors and considerations of the internal party administrative framework and gradually completed the institutional design of the top political levels. In the 17 years prior to the Cultural Revolution, Peng Zhen acted as the highest-ranking decision-making official responsible for leadership over the politics and law branches, an experience that directly influenced the post-Cultural Revolution re-constitution of leadership over politics and law. Given this organizational history, the account here is not just a simple historical narration.

\section{ADMINISTRATIVE COUNCIL COMMITTEE OF POLITICS AND LAW}

In the period after Yan'an, the Central Committee of the CCP started forming a stable first-generation leadership group, with a large number of political, military, and social administration skills having only been recently initiated and formed during the Yan'an period. However, during the armed seizing of power, rule by law as an administrative tool under routinized politics appeared redundant. The model of the CCP Central Committee was governmental leadership under 'triangular organization,' as demonstrated by the Shaanxi-Gansu-Ningxia High Court's only having a total personnel of four and the court's subordination to other administrative units. ${ }^{12}$ Further, as opposed to today's litigation processes, which include the steps of investigation, arrest, complaint, judgment, and enforcement, the most important litigation activities at that time were anti-espionage investigation ('weeding out the traitors') and public security, which were performed via the establishment of working institutions within the CCP Central Committee Social Bureau under the absolute leadership of the Party's Military Personnel Political Department's Anti-Espionage Department. ${ }^{13}$

12 'Shaanxi, Gansu, Ningxia Frontier Region Government, Second Elite Troops Simple Government Implementation Plan,' 11 June 1942, Shaanxi, Gansu, Ningxia Frontier Government Document Archive, 7th edn, Archive Publishing House, 1988, p. 458.

13 See 'Northwest Bureau Instructions Regarding Current Anti-Espionage Issues (Preliminary Draft),' February 1943, CCP Central Committee Northwest Bureau Collected Documents, 1943, Part 1, Section 3, Central Archive, Shaanxi 
'The Party Governing Politics and Law' symbolized the Party governing Public Security.

Before the establishment of the People's Republic of China, previous titles also easily caused confusion regarding these organs: in June 1946, 11 people, including Director Xie Juezai and Wang Ming formed the 'CCP Central Committee Legal Problem Research Committee,' ${ }^{\text {'4 which }}$ held responsibility over 'researching law using new concepts' and drawing up a draft constitution. ${ }^{15}$ In August 1948, this Committee was altered so that Wang Ming became Director, and nine others, including his wife Meng Qingshu, became members of the CCP Central Committee Legal Committee, ${ }^{16}$ which was responsible for tasks including drafting translations of laws and editing books. ${ }^{17}$ Regarding institutional functioning, establishing ideology, and personnel formation, these two units had no legacy tying them to any 'Party Governing Politics and Law' institutions. In the period of military conflict before the establishment of political power, the story of the legal system had not yet begun. ${ }^{18}$

In September 1949, the first meeting of the China Political Consultative Conference opened, representing the founding of the nation and establishment of the government. Before the Second Plenum of the 7th National Congress of the CCP and the successful seizure of political power, Mao

Provincial Archive, ed., 1994, pp.31-37; Li Li, From Underground Battle Lines to Founding General: Remembering My Father Li Ke, Peasant General, People's Publishing House, 2008, pp. 173-174.

14 See The Memoirs of Xie Juezai, Part 2, People's Publishing House, 1984, p. 1157.

15 In 1947, when Mao Zedong led the Kunlun Army in the mountains of Northern Shaanxi Province and met up with $\mathrm{Hu}$ Zongnan's large army, the revolution's prospects were still not very bright. Mao, in a letter to a branch of 'Revolutionary Elders' who were writing a draft constitution, expressed his opinion regarding this branch's work: 'It is not yet the time for issuing Constitutional drafts, and such content is better suited for the deliberation of leadership'; 'legal work is part of the CCP Central Committee's new leadership institutions, with these brothers and Comrade Zhu working so hard on this, it's not what I'd call a nice "retirement."' See 'To Zhang Shushi' (18 November 1947), 'To Chen Jinkun' (16 January 1947), 'To Chen Jinkun' (16 January 1947, 18 November 1947), Selected Letters of Mao Zedong, People's Publishing House, 1983, pp. 290, 292.

16 See 'Chronology of the Life of Xie Juezai', The Collected Works of Xie Juezai, People's Publishing House, 1989, p. 1159.

17 See 'Decision Regarding Central Legal Committee Duties and Organization' (passed by the Central Secretariat, 12 December 1948), Selected Documents of the CCP Central Committee, Vol. 17, Central Party School Publishing House, 1992, p. 563 .

18 Regarding the implications of a silent judicial administration, see US Supreme Court Decisions Ex parte Merryman and Ex parte Milligan. 
Zedong addressed the period of change regarding the Party's internal deployment work duties, saying famously: 'After annihilating enemies who hold guns, there will still be enemies who do not hold guns. ${ }^{19}$ Regarding the policy foundation of 'On the People's Democratic Dictatorship,' which, taken together with the previously-mentioned speech, became 'The Common Plan,' Mao stated even more clearly: 'Our current duty is to strengthen the national machine, which primarily refers to the People's Armed Forces, the People's Police, and the People's Tribunals, to consolidate national defense and protection of the people's interests. ${ }^{20}$

The institutions that specifically assumed the nation's monopoly of violence were established according to the 'Central People's Government Organization Law.' Because the Administration Council Committee could not possibly lead all 30 Central Government ministries, it established four Committees under its authority to assist with every matter. ${ }^{21}$ Among these, the Sub-Committee of the Administration Council Committee of Politics and Law was established, which guided the work of the Ministry of Internal Affairs, the Public Security Department, the Ministry of Justice, the Commission on Legal Affairs, and the Ethnic Affairs Commission. ${ }^{22}$

However, from the beginning, the organizational system of this Committee of Politics and Law was not smooth. Article 5 of the Central People's Government Organization Law stipulates that the Administration Council Committee is the highest enforcement institution in the country, that the People's Revolutionary Military Committee is the country's highest unified military institution, that the Supreme Court and the Supreme Procuracy are the highest adjudicatory and procuratorial bodies, and that these four institutions possess parallel institutional frameworks. Under the Central People's Government Organization Law and the explanations of Zhou Enlai, the organs led by the Political Legal Committee should not in legal principle include the Supreme Court and the Supreme Procuracy Office. But, as Dong Biwu later explained, 'The

19 Mao Zedong, 'Report on the 2nd Plenary Session of the 7th Party Congress' (5 March 1949), Mao Zedong's Works and Selected Readings, People's Publishing House, 1986, p. 654.

20 Mao Zedong, 'On People's Democratic Dictatorship - Remembering 20 Years of the CCP' (30 June 1949), Mao Zedong's Works and Selected Readings, People's Publishing House, 1965, p. 288.

${ }^{21}$ See 'Several Questions Regarding the People's Consultative Conference' (7 September 1949), CCP Central Committee United Front Work Department, Zhou Enlai, Selected Documents on the United Front, People's Publishing House, 1984, p. 142.

22 See Article 18 of the Organization Law of the Central People's Government (1949). 
Committee of Politics and Law's work primarily includes the following four areas: leading, deploying, supervising, and investigating the work of the Civil Affairs Bureau, the Public Security Bureau, the Justice Ministry, the courts, and the procuracy. ${ }^{23}$ Thus, the foundation of the relations between the Political Legal Committee, the courts, and the procuracy was definitely not derived from legal principles, but rather by the commission of Central People's Government Chairman Mao Zedong and Administration Council Committee Premier Zhou Enlai. On October 21, 1949, at the Conference establishing the Committee on Politics and Law, Dong Biwu explained:

the Political Legal Committee will belong to the Administration Council Committee, and it will be responsible for guiding the Ministry of Internal Affairs, the Public Security Bureau, the Ministry of Justice, the Commission on Legal Affairs (法制委员会), and the Ethnic Affairs Commission, and it is commissioned by Chairman Mao Zedong and Premier Zhou Enlai, guiding and communicating with the Supreme People's Court, the Supreme People's Procuracy, and the Administration Council Committee People's Supervision Committee. ${ }^{24}$

In this way, the formal institutional frameworks of the Supreme Court and the Supreme Procuracy Office were parallel with the Administration Council Committee, but at the same time they received guidance from the Administration Council Committee's subordinate Political Legal Committee; obviously, this situation was not conducive to harmonious political and organizational relations.

However, this is only a side issue - the Central People's Government established in October 1949 and its organizational framework were only provisional in nature, organs designed by Mao Zedong for a socialist revolution yet unperformed, and for a period of socialist construction not yet begun.

On 1 October 1949 at 3 p.m., Mao Zedong announced at the Tiananmen Gate Tower that as the Chinese Central People's Government was being established, the Theater 4 38th Western Front Field Army's 113th Troop

23 'Gradually Establish and Augment the Organs of Political Power' (4 November 1951), Selected Jurisprudential Works of Dong Biwu, Law Publishing House, 2001, pp. 200-201.

24 'Commentary Regarding the South Central Bureau's Problems Regarding Party Committees Above the Grassroots Level Establishing Peasant Committees and Governments Establishing Farm Workers' Committees' (8 June 1952), Liu Shaoqi's Documents Since the Founding of the Country, Vol. 4, Central Documents Publishing House, p. 237; The Chronicle of Dong Biwu, Central Documents Publishing House, 1991, p. 348. 
Division was engaged in a fierce battle in Hubei Province, Huaihua Prefecture, with the Guomindang's Liujiashu Military Unit, while the Theater 4 main forces were still on the Northern Front in Huaihua, Baoqing, and Hengyang in Hunan Province, preparing to conduct the Hengbao military campaign against Bai Chongxi. The Theater 1 Field Army and the North China Field Army, 19th Military Unit, had separated to complete the Lanzhou and Ningxia military campaigns and to march into Xinjiang. The Theater 2 Field Army was huddling under cover heading from Jiangsu and Zhejiang to Western Hunan, preparing to attack five provinces in the Southwest, and the Theater 3 Field Army was preparing to attack Xiamen in Fujian Province. ${ }^{25}$ Regarding the Yangtze River's South, Southwest, and Northwest regions, the Guomindang still controlled the majority of these areas, and the newly-liberated areas had not yet conducted land reform, the suppression of counter-revolutionaries, or construction of grassroots political authority. Political and economic foundations of class power had not yet thoroughly changed.

Thus, the Central People's Government created at this time was a unified government, but its entire political framework was only the first in a two-step historical process planned and prepared by Mao Zedong in 1940 for China's New Democratization Revolutionary Period. ${ }^{26}$ Among the Administration Council Committee's four Vice Premiers, two were CCP members, and the others were a Democratic Party member and a member unaffiliated with a party; among 21 Administration Council Committee members, ten were CCP members, and the other 11 members were Democratic-Party-affiliated or unaffiliated members. Among the 93 persons responsible for every department, committee, institute, and office, 51 were CCP members, and 42 persons were members of the Democratic Party or unaffiliated with any party. ${ }^{27}$ From the perspective of serving as

25 See Theater 1 Field Army History Copy Editing Committee, The History of the China People's Liberation Army Theater 1 Field Army, Liberation Army Publishing House, 1995, pp. 274-297; Theater 2 Field Army History Copy Editing Committee, The History of the China People's Liberation Army Theater 2 Field Army, Liberation Army Publishing House, 1990, pp. 294-295; Nanjing Military District, 'Theater 3 Field Army History' Editing Office, The History of the China People's Liberation Army Theater 3 Field Army, Liberation Army Publishing House, 1996, pp.382, 299-415; Theater 4 Field Army History Copy Editing Group, The History of the China People's Liberation Army Theater 4 Field Army, Liberation Army Publishing House, 1998, pp. 528-531.

26 See Mao Zedong, 'New Democratic Theory,' Liberation, 1940, Issues 98, 99, pp. 23.

${ }_{27}$ See CCP Central Committee Document Research Office, ed., Zhou Enlai's Biography (1949-1976), Central Documents Publishing House, 1998, pp. 3-4. 
a personnel organization form unifying the government Administration Council Committee Political Legal Affairs Committee, the CCP Central Committee did not wholeheartedly entrust this organ with a political legal leadership role.

Dong Biwu became Director of the Political Legal Committee that was established in October 1949, and the Vice Directors were Peng Zhen, Zhang Xiruo, Chen Shaoyu, and Peng Zemin. Among these five people, Director Dong Biwu was a Central Politburo member and Vice Premier of the Administration Council Committee. Among the four Vice Premiers at that time, Dong Biwu ranked Chen Yun as the top Vice Premier. During this period, Peng Zhen jointly held positions including Central Politburo Member, Central Secretariat Alternate Secretary, ${ }^{28}$ Chief of the Central Organization Department, Central Policy Research Office Director, First Secretary of the Beijing Municipal Party Committee, and Beijing Mayor, but his primary energy was devoted to the early work of establishing the capital of Beijing. ${ }^{29}$ For these officials, their political legal positions were primarily that of a figurehead.

Among the other three Vice Directors, Peng Zemin, who had returned from abroad and had previously held the position of Director of the Overseas Department for the Republican Government, went thereafter to Hong Kong to practice medicine, and after the founding of the PRC became Vice Chairperson of the Chinese Peasants and Workers Party. ${ }^{30}$ Zhang Xiruo was not affiliated with any party and served as professor of politics at Tsinghua University. ${ }^{31}$ After the 'Yan'an Rectification Campaign,' and especially following the 2nd Plenum of the 7th Meeting of the Central Committee of the CCP, Chen Shaoyu (a.k.a. Wang Ming) accepted the post of Vice Director, but he seemed to consider this new institution weak. ${ }^{32}$ During his time as Political Legal Committee Vice

28 Between 1945 and 1956, the CCP Central Committee had not yet established a Politburo Standing Committee, but had established a Central Secretariat Secretary. The status and authority of this organ and that of the post-1956 Central Secretariat were different.

29 After March 1953, Peng Zhen took over from Dong Biwu as the Political Legal Committee Party Leading Sub-Group Secretary, and started more general responsibilities over comprehensive political legal affairs. See Peng Zhen's Biography, Vol. 2, Central Documents Publishing House, 2012, p. 868.

30 See, The Memoirs of Xiao Ke, Liberation Army Publishing House, 1997, pp. 56-57.

31 See The Memoirs of Pu Xuefeng: In a Dream Thousands of Miles from Home, Huangshan Publishing House, 2009, p. 157.

32 In the five years after the 7th Plenary Session of the 6th Party Congress and the 7th Party Congress, Mao Zedong's conclusion at the 2nd Plenary Session 
Director and Legal Affairs Committee Director, Wang Ming drafted the Provisional Marriage Law, ${ }^{33}$ but from October 1950 until December 1953, he went with his wife and daughter to Moscow to recuperate from an illness, returning again in January 1956 to the Soviet Union to recover from illness, and then stayed there until his death in 1974. Perhaps indicating that he believed that these political legal positions were substantially marginalized, Wang Ming, in an autobiographical work corresponding to debates between the Central Soviet Communist Party and the CCP, did not write a word regarding his position as Vice Director of the Political Legal Committee. ${ }^{34}$

Regarding the Administration Council Committee Political Legal Committee's 47 members ${ }^{35}$ the following list summarizes the types of political party memberships held:

(1) The CCP (17 members): Luo Ronghuan (Supreme Procuracy Office, Director), Wu Gaizhi (Supreme Court, Vice President), Li Liuru (Supreme Procuracy Office, Vice Director), Xie Juezai (Internal Affairs Bureau, Director), Wu Xinyu (Internal Affairs Bureau, Vice Director), Luo Ruiqing (Public Security Department, Director), Yang Qiqing (Public Security Department, Vice Director), Li Muan (Ministry of Justice, Vice Director), Zhang Shushi (Legal Affairs Commission, Vice Director), Li Weihan (Ethnic Affairs Commission, Director), Wu Lanfu and Liu Geping (All-System Ethnic Affairs Commission, Vice Directors), Tao Xijin (Political Legal Committee, Secretary General), Wu Yuzhang (CCP Central Committee Member), Deng Yingchao (All China Women's League Vice Director), Liao Chengzhi (All China Youth League, Chairperson), Xie Xuehong (Taiwan Democratic Self-Government League, Chairperson).

(2) Non-CCP Democratic Parties and Those Unaffiliated with a Party (30 members): Shen Junru (Supreme Court President), Zhang Zhirang (Supreme Court Vice President), Sai Fuding (Ethnic Affairs

of the 7th Party Congress was still concentrated on discussing the Wang Ming problem. Regarding Wang Ming's ultimate political opinions, see 'Conclusion at the 2nd Plenary Session of the 7th Party Congress,' 13 March 1949, Collected Works of Mao Zedong, Vol. 5, People's Publishing House, 1996, pp. 263-265.

33 See Dai Maolin and Cao Zhongbin, The Biography of Wang Ming, CCP History Publishing House, 2008, pp. 261-276.

34 See Wang Ming, 50 Years of the CCP, Xu Xiaoying et al., translators, Eastern Publishing House, 2004, p. 48.

35 See 'Name List of Political Legal Committee Directors, Vice-Directors, and Members,' The People's Daily, 20 October 1949. 
Commission, Vice Director), Lan Gongwu (Supreme Procuracy Office, Vice Director), Chen Qihuan (Internal Affairs Department, Vice Director), Shi Liang (Ministry of Justice, Director), Xu Deqi and Shen Jinkun (All-System Legal Affairs Commission, Vice Director), Zhang Wen and Zhang Baozhen (All-System Revolutionary Committee of the Guomindang,StandingCommitteeMember),LiRenren(Revolutionary Committee of the Guomindang, Executive Committee), Zhou Jingwen, Liuwang Liming, and Ye Duyi (All-System Taiwan Democratic SelfGovernment League, Central Committee), Guo Guanjie and Guo Zechen (All-System Chinese Peasants and Workers Party, Executive Committee), Huang Qixiang (Chinese Peasants and Workers Party), Chen Mingshu, Guo Chuntao, and Xu Baoju (the People's Comrade Federation, Central Standing Committee), Chen Yansheng (China Party for the Public Interest, Central Standing Committee), Yi Liyu (All-China Federation for Trade Unions, Standing Committee), Li Xiuzhen (peasant labor hero), Deng Chumin (professor), Wu Yaozong (Young Men's Christian Association Editor's Department, Director), Zhou Shanpei (business domain), Yan Huiqing (charity domain), Lin Zhongyi, Zhang Shizhao, and Jiang Yong (all-system lawyers).

In this way, one person constituted an entire institution, and there was a characteristically unified battlefront organization style; however, in terms of politics, it was relatively difficult to completely implement Communist Party planning. When Liu Shaoqi visited the Soviet Union in 1949, Stalin was quick to remind the CCP Central Committee of this point. The report that Liu Shaoqi gave Stalin showed the entire Political Consultative Conference personnel structure:

Right now, the Political Consultative Conference preparations have already been formed, and altogether there has been prepared a committee of 134 people, and among them CCP members make up 43 people, and we are progressing along with 48 people who are definitely forging ahead with us; among the 43 remaining people, there are only 16 rightists, among those forging ahead with us, there are 15 underground Party members. Regarding the Political Consultative Conference, the CCP can guarantee absolute leadership. ${ }^{36}$

Among the 30 members without party affiliation in the Political Legal Committee, Sai Fuding was soon to enter the Party, others such as

36 'Report Given on Behalf of the CCP Central Committee to Stalin' (4 July 1949), Liu Shaoqi's Documents Since the Founding of the Country, Vol. 1, Central Documents Press, 2005, p. 4. 
Xu Deqi and Chen Jinkun 'would definitely forge ahead,' Li Xiuzhen among other peasants was emancipating Shanxi, the areas near Northern Mongolia, and Hebei, and still others were underground Party members. But ultimately, there were still several 'half-hearted' and 'divided loyalty' members.

The discussion above indicates that the Political Legal Committee's authority was to 'lead, deploy, supervise, and inspect' the Ministry of Civil Affairs, the Public Security Bureau, the Ministry of Justice, the courts, and the Procuracy Offices, as well as to lead or link up with the Ethnic Affairs Commission, the National Supervisory Committee, and other departments possessing significant authority. Among these, the Public Security Bureau was merged from the CCP Central Committee Social Bureau and the CCP Central Committee North China Society Bureau. It was also the earliest to enter the chain of the Central Military Commission as the Central Military Commission Public Security Bureau, which was under the leadership of the CCP, making it an institutional organ wielding both the 'barrel of the gun' and the 'power of the sword.' The members who were unaffiliated with a party cut into these key positions and conflicted with the political line of the Leninist party. At the All-China Public Security Bureau Conference, Peng Zhen openly expressed this worry:

\begin{abstract}
Democratic types demand that everything be made known, even wanting to understand criminal investigation work and to participate in criminal investigation conferences - that is not acceptable. . All day we are with these democratic types and enlightened types, and we do not believe that they will influence us; but in reality, they have their own style of living, and just as the Political Legal Committee always wants to influence us police, even regarding terminology, this Committee will still want to persist. We are leading and remaking the democratic types, and so we must be constantly vigilant, otherwise we will be influenced by them. ${ }^{37}$
\end{abstract}

The united government and the interim regime's distinctive features were also obvious even when not examining the membership of the Political Legal Committee and instead simply examining the Committee's guidance and coordination of the Public Security Bureau, the committees, the courts, and the Procuracy. Supreme Court President Shen Junru and the Ministry of Justice Director Shi Liang were both members of the China Democratic League. Supreme Court Vice President Zhang Zhirang

37 'Speech of Comrade Peng Zhen at the 4th National Public Security Conference' (17 September 1951), Selected Public Security Conference Documents (October 1949-September 1957), published in September 1958 by the Public Security Bureau, pp. 114-115. 
previously was a judicial officer in the Beiyang Government and was unaffiliated with a party at that time..$^{38}$ Due to Supreme Procuracy Office Director Luo Ronghuan's debilitating kidney cancer, and due also to his primary devotion to his post in the General Political Office and the Cadre Corps of the People's Liberation Army, procuratorial work was primarily directed by two Vice Presidents; among these two, Lan Gongwu was not affiliated with a party. ${ }^{39}$ People's Supervisory Committee Director Tan Pingshan was expelled from the CCP in November 1927, when he was serving as a Standing Committee member of the Revolutionary Committee of the Guomindang. ${ }^{40}$ In the Public Security Bureau and in the Court internal units, when assuming control over Guomindang police bureaus and courts, many old cadres and personnel were retained ${ }^{41}$ and stayed on to conduct judicial reform.

Given these circumstances, the CCP Central Committee selected a different path for administrative institutionalization.

\section{SUB-COMMITTEE OF ADMINISTRATION COUNCIL COMMITTEE OF POLITICS AND LAW}

As early as 1927, when the third re-drafting of the CCP Constitution began, the CCP Central Committee organized a Party team 'in every non-party mass conference and executive organ (Guomindang, Republican Government, trade union, peasants association, etc.)' as an administrative countermeasure. ${ }^{42}$ After the 7 th Party Congress, the Party leadership organizations located 'in government, trade unions, peasants' associations, cooperatives and other mass organizations' leadership branches' changed their titles from

38 See 'New China First Generation Major Judge Zhang Zhirang,' published in October 1995 by the Political Consultative Conference Wujin Committee Documentary History Material Research Committee, pp. 37-69.

39 See Luo Dongjin, My Father, Luo Ronghuan, Liaoning People's Publishing House, 2003, p. 322.

40 See Yuan Bangjian, The Biography of Tan Pingshan, Heilongjiang People's Publishing House, 1986, pp. 124, 164.

41 See 'Suggestions Regarding Taking Control of the Pingin Guomindang Judicial Organs' (passed by the Central Secretariat on 21 January 1949), Selected Documents of the CCP Central Committee, Vol. 18, Central Party School Publishing House, 1992, pp. 59-62.

42 See 'Resolution on the 3rd Amendment to the CCP Constitution' (Resolution of the Central Politiburo Conference of 1 June 1927), CCP Constitution Collected Materials - From the First to the Seventeenth Party Congress, CCP History Publishing House, 2007, p. 29. 
'Party Team' to 'Party Leading Group. ${ }^{43}$ In November 1949, the Supreme Court and the Supreme Procuracy Office established a unified Party Leading Group, with Luo Ronghuan as Party Leading Group Secretary. However, regarding the Supreme Court and Supreme Procuracy Office's primary duties, a working distinction arose between the Supreme Court Party Leading Group Vice Secretary Wu Gaizhi and Li Liuru, the internal Party Vice Procuratorial Director and Party Leading Group Secretary. Li Muan held the Central Government Ministry of Justice's actual leadership position: the CCP Central Committee Ministry of Justice Party Group Secretary. In this way, the leadership of the Public Security Bureau, the courts, and the Procuracy Offices, and the internal Party Leading Group of the Ministry of Justice had to originate from a CCP organ rather than from an organization lacking 'unified battle line' character.

On January 9, 1950, the Administration Council Committee General Party Leading Group Cadre Conference convened with 11 attendees altogether, including Zhou Enlai as the Secretary. The Political Legal Party Leading Sub-Group Cadre Conference had nine attendees, including Dong Biwu as Secretary. Peng Zhen was among the eight others present. On January 15, 1951, the CCP Central Committee ordered adjustment to the Political Legal Committee Party Leading Group Sub-Committee on Cadres, adding Peng Zhen and Luo Ruiqing as Sub-Committee Vice Secretaries and $\mathrm{Wu}$ Gaizhi as well as four others as Sub-Committee Members. ${ }^{44}$

Following these developments, the most important policy instruction regarding politics and law was not issued from the Central People's Government nor was it issued from the Administration Council Committee to the Politics and Law Committee; rather, it was issued by the CCP Central Committee and the Administration Council Committee's General Party Leading Group (总党组) Sub-Committee to the Politics Legal Party Leading Sub-Group (分党组) Sub-Committee. ${ }^{45}$ The Political Legal Party Leading Sub-Group Sub-Committee issued the decisions regarding the important working systems internal to the Political Legal organs. Using

43 See Article 60 of the CCP Constitution (passed by the 7th Party Congress on 11 June 1945).

44 See The Chronicles of Peng Zhen, Vol. 2, Central Documents Publishing House, 2012, pp. 95, 115.

45 See 'Circular of the Central Committee to the Political Legal Committee Party Leading Sub-Group Regarding Judicial Reform Work Reports,' 9 July 1952, Liu Shaoqi's Documents Since the Founding of the Country, Vol. 3, Central Documents Publishing House, 2005, pp.311-313; 'Commentary on the Central Committee Circular Regarding the Problems of the Political Legal System and Cadre Allocations,' March 1953, Liu Shaoqi's Documents Since the Founding of the Country, Vol. 5, Central Documents Publishing House, 2008, p. 91. 
the Party Leading Group's internal Party style, orders were served upon the Party Leading Groups of the Public Security Bureaus, Procuracy Offices, courts, and the Ministries of Justice, constituting the prominent and characteristic style of political operations in this period. ${ }^{46}$ At the 4 th Plenary Session of the 1951 All-China Public Security Conference, Peng Zhen commented:

Are Party leaders open to the public or secret? Legal or illegal? In the past we have been very vague, but we should clearly be open to the public and legal. When our Party actually leads, we don't say or acknowledge this point, leading the democratic types to be suspicious . . . not knowing from which direction the wind blows, it is as if the Party leaders are not allowed to discuss it. ${ }^{47}$

Before and after July 1952, Dong Biwu, Peng Zhen, and Luo Ruiqing all fell ill, leading Dong Biwu to convene a special meeting of leaders from the five Political and Legal branches at the office-level (処级) and above. At the meeting, he emphasized: 'When the work of the five branches is taken from leadership of the democratic types, and the Party does not rely on the collective power of Party Committees, branches, and ministries, then what does it rely on? ${ }^{48}$ Zhou Enlai, in presiding over the Administration Council Committee's 202nd Politics and Law Conference, discussed the Politics and Law Committee's 'Main Duties of Politics and Law Work in 1954,' and said that in completing the work of the Public Security, Procuracy, and Supervisory organs, the unified leadership of Party politics comes first. ${ }^{49}$

However, this internal Party style, by which leadership is executed via Party Leading Groups, goes against the fundamental internal Party tactics relating to handling tiao and kuai relations. According to the seven major CCP Constitution regulations: 'Party Leading Group Sub-Committees and Secretaries are appointed from affiliated Party Committees. Party Leading Groups obey the leaders of every

46 See The Biography of Dong Biwu (1886-1973), Central Documents Publishing House, 2006, pp.739, 752, 784, 789; The Chronicle of Dong Biwu, Central Documents Publishing House, 1991, p. 385.

47 Supra note 37, p. 114.

48 'Key Points from Political Legal Departments' Party Members Responsible Comrades' Discussion,' (July 1951), Selected Political Legal Works of Dong Biwu, Law Publishing House, 1986, pp. 164-166; see, 'Respect Non-Party Responsible Cadres, Strengthen Collaboration Between Those Inside and Outside the Party' (16 July 1952), Selected Jurisprudential Works of Dong Biwu, Law Publishing House, 2001, pp. 138-143.

49 See The Chronicle of Zhou Enlai (1949-1976), Central Documents Publishing House, 1997, p. 346. 
corresponding level Party Committee and execute their decisions' ${ }^{50}$ These provisions eliminate leadership relations between Party Leading Groups and instead mandate compliance with the Party Committees that produced them. In November 1949, the CCP Central Committee decided to establish a Party Leading Group in the Administration Council Committee, and within the Political Legal Committee, four Committees established four Party Leading Sub-Groups. Also, the Supreme Court and the Supreme Procuracy Office established a unified Party Leading Group. According to the seven major CCP Constitutional regulations, the Administration Council Committee Party Leading Group, the Political Legal Party Leading Sub-Group, and the unified Supreme Court and Supreme Procuracy Office Party Leading Group all act as Party Leading Groups with parallel relations within the Party. The CCP Central Committee also reiterates the principle that:

There are no leadership relations between the Administration Council Committee Party Leading Group and the Supreme Court and Supreme Procuracy Office's unified Party Leading Group. These institutions all belong directly under the leadership of the Central Politburo. Every decision of the CCP Central Committee related to government work must guarantee enforcement and cannot violate [this principle]. ${ }^{51}$

Other than this problem within the Party's internal system, the Political Legal Committee and its Party Leading Sub-Group Sub-Committee also experienced a substantial problem regarding operational efficiency. The four Committees established by the Administration Council Committee were not trivial working organs. Rather, these committees established completely new hierarchies between every bureau, committee, and institution of the Central People's Government and the Administration Council Committee, breaking the basic governmental regulations in the Organization Law. Zhou Enlai stated, 'The establishment of the Administration Council Committee's four Committees essentially means every Committee is basically a Sub-Committee of the Administration Council Committee. ${ }^{52}$ Dong Biwu explained more clearly:

\footnotetext{
50 Articles 61 and 62 of the CCP Constitution (passed by the 7th Party Congress, 11 June 1945).

51 'Decision of the CCP Central Committee Regarding Central Government Internal Establishment of Party Leading Groups' (November 1949), CCP Organizational History Materials, Vol. 9, CCP History Publishing House, 2000, pp. $9-10$.

52 'Must Strengthen Cultural Education Work' (24 October 1952), Zhou Enlai's Selected Materials on Education and Culture, Education Science Publishing House, 1984, p. 71.
} 
Regarding linking and leadership committees, e.g., Politics and Law, Finance, Culture and Education, previously there existed three different opinions regarding whether the 4th Small Group's discussions constitute a top-level problem: one, count it as top-level, these problems are similar in importance to writing the current Organization Law. Two, do not count it as top-level, do not boss people around. Three, do not regulate whether this counts as top-level and instead decide from actual developments. Currently under the Administration Council Committee there are 30 bureaus, and if every week one conference were convened, it would only be able to discuss the work of one bureau that week, and very few bureaus' work could be discussed in one month. In order to patch up this defect, therefore, this topic definitely should be taken as top-level so as to link and lead the bureaus' work. In this way, every bureau's work receives double leadership - that of the Administration Council Committee and that of the leading committee to which that bureau belongs.

Dong Biwu also emphasized that the Politics and Law Committee, having 'four Committees, possesses relatively high status, and therefore it has a higher status in the party's organizational system. The bureaus led by the Politics and Law Committee are indicated by the yellow line'. Regarding leadership committees such as politics and law, the Administration Council Committee and every bureau, association, office, institution, and profession all have direct command authority, and the black line indicates this. ${ }^{53}$ In this time period, in the central hierarchy, the offices responsible for document information collective work were the Administration Council Committee Office, the Central People's Government Office, and the CCP Central Committee Office.

The three-level system internal to the Central Government can be seen in the political legal organs' specific operations and in the following illustration: in July and August 1950, the Public Security Bureau convened an All-China Safety Management Administrative Work Conference, with the Internal Affairs Bureau convening the First All-China Civil Affairs Conference, and the Supreme Court, the Supreme Procuracy Office, the Ministry of Justice, and the Political Legal Committee convening the First All-China Judicial Conference. After these three conferences concluded, the Political Legal Party Leading Sub-Group Secretary Dong Biwu on August 12 wrote a report for Zhou Enlai (who was, at the time, the Administration Council Committee General Party Leading Group SubCommittee Secretary) regarding the situation of the conferences, raising

53 See Dong Biwu, 'The Passage and Basic Content of the PRC Central People's Government Organization Law First Draft' (22 September 1949), Collection of Important Documents Since the Establishment of the Party, Vol. 26, Central Documents Publishing House, 2011, p. 741. 
problems that the Central Government needed to research and resolve. Zhou Enlai 'had some opinions regarding this report,' and after delaying for a moment, sent the report to CCP Central Committee Secretary and Central People's Government Chairman Mao Zedong. ${ }^{54}$

From this system, three points can be analyzed. First, from every institution, bureau, committee, office to the Administration Council Committee's four Committees (Party Leading Sub-Group Sub-Committee), to the Administration Council Committee (General Party Leading Group SubCommittee), to the Central People's Government and CCP Central Committee - not counting the local large districts, provinces, special offices, and counties - it is only the central, top level that has this kind of multi-layered structure, with low efficiency and difficult-to-overcome information deficiencies between hierarchies. Second, the Administration Council Committee (General Party Leading Group Sub-Committee) becomes the primary procedure for every bureau, committee, institution, Supreme Court, and Supreme Procuracy Office (Party Leading Group), except the Central Military Commission, to report and ask for instructions from the Central People's Government and CCP Central Committee Chair. Third, the Administration Council Committee, committees (Party Leading Sub-Group Sub-Committee) and General Party Leading Group Sub-Committees do not simply present and submit requests from every bureau, committee, and office (Party Leading Group) for instructions and reporting to the CCP Central Committee; rather, requests are processed and filtered according to a particular organ's importance. In this way, the CCP Central Committee was actually set aside and away from frontline work.

Mao Zedong very quickly perceived this problem, and in Mao Zedong's style, meted out severe criticism. Mao Zedong told the Public Security Bureau Director Luo Ruiqing that reports should be given directly to him, and that not directly giving them to him was unacceptable: 'After all, we have storage warehouses for documents here. ${ }^{55}$ Luo Ruiqing immediately

54 See 'Commentary and Notes on Party Leading Group Report Given to the Administration Council Committee by Dong Biwu' (17 August 1950), 'Letter Regarding Giving Political Legal Units Summary Reports to Mao Zedong' (13 September 1950), Documents of Zhou Enlai Since the Founding of the Country, Vol. 3, Central Documents Publishing House, 2008, pp. 165, 168-171, 292-293.

55 In August and September 1950, the Director of the Central Military Committee Intelligence Agency, Li Kenong communicated to Luo Ruiqing that he had spoken to Chairman Mao and that Mao said that the Public Security Bureau did not do reports for him, and that he was very angry about this. Luo Ruiqing immediately went to see Mao, who first asked him why he did not write reports for him, and Luo Ruiqing said that he wrote reports. Mao said: 'Written, then let me 
took all of the documents summarizing the All-China conferences on safeguarding the economy convened by the Public Security Bureau and gave them to Mao Zedong. In these documents drafted by Luo Ruiqing, there were several places in which it was noted for the Party leader, 'previously deleted by a responsible comrade, ${ }^{56}$ regarding which Mao commented:

Every place in which the content of Party leaders' documents is deleted or amended to produce ambiguous wording or unsophisticated administrative leadership, the original manuscript is correct and what is deleted is incorrect, and the original should be restored. Security work must in particular emphasize the Party's leading function, and in reality accept the Party Committee's direct leadership; otherwise, there is danger. ${ }^{57}$

On September 13, 1950, Mao Zedong also wrote Zhou Enlai a highly critical letter: 'All the bureaus in the Political-Legal System, other than Li Weihan's Ethnic Affairs Committee and those connected to the central government, for a year's time, what have they done? What policies have they carried out? No one knows. Please tell me why.' Mao Zedong required that 'regarding the above situation, please do a summary investigation, and please be quick.' 58

Organizational imperfections, low efficiency, Mao Zedong's political considerations, and considerations for consolidating the regime's personnel plans during the interim period all prevented the Politics and Law Committee Party Leading Sub-Group Sub-Committee from operating smoothly.

In 1952, after the Korean War stabilized on the battlefield and the situation there shifted toward negotiations, the CCP Central Committee began to focus on domestic affairs. In June and July 1952, the CCP Central Committee set out to take large districts' Secretaries and transfer them to the center. Regarding large districts and central bureaus, as well

see the receipt.' See Dian Dian, Uncommon Times, Shanghai Literature and Art Publishing House, 1987, pp. 146-147. The author of this book, Dian Dian, is Luo Ruiqing's daughter, Luo Yuping (Luo Diandian).

56 Huang Yao et al., Biography of Luo Ruiqing, Contemporary China Publishing House, 1996, pp. 263-264.

57 'Commentary on the Summary of the National Economic Security Work Conference' (27 September 1950), Documents of Mao Zedong Since the Founding of the Country, Vol. 1, Central Documents Publishing House, 1987, p. 535 (emphasis in original).

58 'Commentary on the Report Work to the Central Committee Regarding Inspection and Supervision of Government Units' (13 September 1950), Documents of Mao Zedong Since the Founding of the Country, Vol. 1, Central Documents Publishing House, 1987, p. 513 (emphasis added). 
as large district governments' limits on authority, the hierarchy for the six large administrative districts was gradually eliminated, and unified CCP Central Committee authority over every affair was added. ${ }^{59}$

After the 'The New Tax Issue' occurred, Mao Zedong accelerated systemic transformation. On December 31, 1952, The People's Daily published the Administration Council Committee's 'Report Regarding Several Amendments to the Tax System and Their Implementation Period,' which implemented 'public and private uniform and equal tax payments.' The result was commodity price fluctuation and panic buying across localities. Only after reading newspapers and the reports from localities including the Shandong Sub-Bureau and the Beijing Municipal Party Committee, did Mao Zedong learn of the issue concerning the new tax system. On January 15, 1953, he raised criticisms with people such as Zhou Enlai and Finance Department Director Bo Yibo, believing that the issue of the Administration Council Committee amending the tax system had not first been reported to the Center and was a mistake of 'rightist opportunism. ${ }^{90}$ In the same year, on March 10, the CCP Central Committee issued a regulation stating, 'After today, all primary and important policies, plans, and major items must first receive instructions from the Center; only then, through the completion of the Center's discussions and decisions or approvals, can enforcement begin'; the regulation further stated:

every committee, bureau, association, institution, office, and profession belonging to the Administration Council Committee must directly propose Administration Council Committee commentary or handling of the matter; other than routine affairs, items which involve policies or plans all should be limited to issues already discussed and decided by the Center, plans already approved by the Center, or problems within the scope of approved principles.

Further, the regulations indicate that 'there does not exist a need for the Government Party Leading Group Sub-Committee, and it should be immediately eliminated. ${ }^{61}$

59 Before the large organizational changes, fine tuning internal to the Central Committee's working organs eliminated the Central People's Government General Office's work organs in three offices, see Qi Yanming, 'Letter to Premier Zhou and Chairman Mao Regarding Eliminating the Central People's Government General Office's Work Organs,' 5 November 1950, Ma Yongshun et al., eds, Collected Works Remembering Ji Yanming, China Literature History Publishing House, 2006, p. 84.

60 See Bo Yibo, A Look Back on Several Major Policy Decisions, Central Party School Publishing House, 1991, pp. 233-235, 250.

61 'Decision of the Central Committee Regarding Strengthening the System of Government Units Requesting Instruction Reports from the Central People's 
In the period of Mao Zedong's planning and preparing for a new system of government, another important event occurred in 1953. On December 24, 1953, Mao convened and hosted an expanded Central Politburo conference, at which he said that after the problem of the 'two headquarters,' a small constitutional drafting group including Chen Boda, Hu Qiaomu, and Tian Jiaying would take a special train that afternoon leaving Beijing for Hangzhou to draft the Constitution. ${ }^{62}$

A context in which newly occurring and presently occurring events are taking shape most directly influences awareness of these events. All of the fundamental political and administrative structures ultimately expressed in the 1954 Constitution occurred in the aftermath of the events described above. Mao Zedong, from his stay in Hangzhou until the adoption of the Constitution in September 1954 at the First National People's Congress (NPC), established the 'one government, two institutions (i.e., court and procuracy)' system under the leadership of the NPC. The 'Central People's Government' title was altered to refer only to the State Council, which included only the highest administrative organs, ${ }^{63}$ with the NPC and the 'one government, two institutions' all accepting the leadership of the CCP Central Committee.

The new structures, according to the ' 8 Verses' Mao Zedong composed in 1953, were to do the following: 'Centralize major powers/Distribute minor powers/With Party Committees deciding/With each locality implementing/Implementation is also decision-making/Do not deviate from principle/Work inspections/Are Party Committees' responsibility. ${ }^{94}$

In October 1954, after the change in basic political administrative structures, Zhou Enlai hosted the State Council's First General Meeting,

Government and Strengthening the Central Committee Regarding Government Work Leadership (Draft)' (10 March 1953), Selection of Important Documents Since the Founding of the Country, Vol. 4, Central Documents Publishing House, 1993, pp. 67-72; supra note 27, pp. 136-137.

62 See Feng Xianzhi, Mao Zedong and His Secretary Tian Jiaying, Dong Bian et al., ed., Mao Zedong and His Secretary Tian Jiajing, Supplement, Central Documents Publishing House, 1996, p. 46; 'Speech at the CCP National Conference,' March 1955, Collected Works of Mao Zedong, Vol. 6, People's Publishing House, 1999, p. 398.

63 The 1954 Constitution, Article 47 stipulates, 'The State Council, i.e., the Central People's Government, is the executive organ of the highest organ of state power; it is the highest organ of state administration.'

64 Mao Zedong said, 'These 8 Verses were written in 1953 to oppose the fragmentationist thought emerging at the time.' 'Outline of Conclusions from the Nanning Conference' (21 January 1958), 'Work Methods, 60 Articles (Draft),' January 1958, Manuscripts of Mao Zedong Since the Founding of the Country, Vol. 7, Central Documents Publishing House, 1992, pp. 30, 57. 
producing the 'State Council Organization and Work Problems' report, and also deciding that the State Council would establish offices in the Political-Legal, Cultural and Education, Heavy Industry, Light Industry, Finance, Treasury, Trade, Transportation, Agriculture, Forestry, Water, Capitalist Industry and Commerce domains and amend them into an order form the 1st through to the 8th offices. Among these, Public Security Bureau Director Luo Ruiqing took the concurrent post of State Council's First Political and Legal Office Director, assisting the work of the relevant units led by the Premier. In November 1954, through the approval of the 2nd Conference of the 1st NPC Meeting, the State Council issued the Circular Regarding Establishing and Adjusting the Central and Local Administrative Organs of the Country and Relevant Issues, establishing the eight above-mentioned Offices and assisting the Premier in dividing and controlling the work of State-Council-affiliated units, ending the work of the original Political Legal Committee organ that had been affiliated with the Central People's Government Administration Council Committee. ${ }^{65}$

Until this point, there had been no specific organ to lead political-legal government branches and work issues at the top levels of government.

\section{THE CENTRAL LEGAL COMMITTEE}

Upon issuing and implementing the 1954 Constitution, the People's Court Organization Law, the People's Procuracy Organization Law, and in constructing judicial systems in the pattern of modern, Western systems, it was not long before the CCP Central Committee noticed the tensions between judicial practice and already-existing political concepts.

Originally, according to Dong Biwu's statements in 1951, establishing the Political Legal Committee's work primarily consisted of the following four points: (1) leading, deploying, supervising, and inspecting the work of bureaus including the Civil Affairs Ministry, the Public Security Bureau, the Ministry of Justice, the courts, and the Procuracy Office; (2) taking responsibility over communications between units, helping each other's work, coordinating with each other, and amicably resolving problems; (3) under unified leadership, political and legal units can fully cooperate; (4) political and legal units' strength is not identical, and units should take care of and draw close to each other. ${ }^{66}$

However, at the beginning of the establishment of political authority,

65 Supra note 48, p. 419.

66 See supra note 23. 
every political and legal government branch had very few personnel, making it difficult to launch the work of these institutions. In July 1951, one in four counties did not have courts, and among more than 2,200 counties and municipalities, only 300 had Procuracy Offices; even the most robust component of the political and legal section of the government, the Public Security Bureau, still had more than 80 counties without a primary Director ${ }^{67}$ On January 29, 1950, the CCP Central Committee, in its Report Regarding the Central People's Procuracy Office Four Regulations, mandated the following:

1. Because of the lack of cadres and for the sake of convenience, every level Procuratorial organ can temporarily set up together with Public Security units. 2. It is best that every level's Procuracy Director temporarily select a person from the Public Security Bureau's Director or Vice-Director level to hold concurrent posts, and then select someone to serve below that person, who can do more specialized procuracy work. ${ }^{68}$

Thus, during the period of land reform, several people were chosen from the Peasants' Association to serve as judicial officers, whereas in cities, several people were chosen from trade unions and other people's groups to serve as judicial officers. County and municipal governments appointed several judicial officers, who then formed People's Tribunals to conduct adjudication, and People's Tribunals had authority to pronounce sentences of death and imprisonment. The organ at one level above the People's Tribunals was the county or the municipal government. When defendants refused to comply with the decisions of courts, they complained to county or municipal governments' Ministry of Justice units. ${ }^{69}$ From the 'October 10 Instructions' in 1950 until the suppression of counter-revolutionaries in Xinan, Xibei, Changjiang, and through the Southern, large-scale, militarily-administered regions, the judging

67 See 'Explanation Regarding Planning to Establish a Central Political Legal Cadre School' (20 July 1951), 'Current Political Legal Work's Main Points and Several Problems Regarding Personnel in Political Legal Units' (11 September 1951), Collected Political Legal Works of Dong Biwu, Law Publishing House, 1986, pp. 161, 168.

68 'Report of the CCP Central Committee Regarding Four Regulations of Central People's Procuracy Office,' Reference Materials of the Procuracy System, Vol. 1 (New China Section), edited and published by the Supreme People's Procuracy, 1980, p. 21.

69 See 'Regulations of the CCP Central Committee Regarding Divisions of Social Class and Salary in Land Reform (Draft),' Selected and Edited Documents From the War of Liberation Period and From Land Reform (1945-1949), Central Party School Publishing House, 1981, pp. 226-227. 
of disputes was handled by the military headquarters at each level, the military supervision committee, or by military tribunals organized by antibandit organs. ${ }^{70}$ After the contraction of May 1951, approvals for arrests came from a special office at the level of the prefectural Party committee, and for murder cases, approval came from the provincial level. ${ }^{71}$

Based on the above, the following summary is possible. First, the work between the permanent organs of the Public Security, procuracy, and courts to 'take care of and draw close to each other,' did not result in breakdown. Second, even though the already-established organs of police, procuracy, courts, and Ministry of Justice occasionally had differences of opinion, every organ handled affairs according to the terse leadership policy decisions of the Party, without the settled, systemic conflicts, checks, and balances of procedural and substantive law. Third, during this time, the political and legal system became 'Big Police, Little Politics and Law,' with the Public Security Bureau acting as the ultimate 'captain,' and the vulnerable, marginalized 'two institutions (两院)' of the court and the procuracy, along with the Ministry of Justice, becoming work coordinators and assistants. Thus, neither an investigative center in conflict with a judicial center, nor any other conflicts between investigation, judging, and procuratorial supervisory authority emerged among the political and law organs. Fourth, under the litigation structures and investigatory ideology emerging since the war era, the Public Security Bureau was led very closely by the Party Committee, and the Party grasped police work as being at the core of the entirety of political-legal affairs; for example, in October 1949, as Zhou Enlai said in an interview with participating personnel at the All-Country Public Security Work High-Level Cadre Conference:

the army and public security units are the main pillars of political power. You are the nation's institutions for providing safety and preventing danger - each one half. National safety and danger, you shoulder half of the responsibility, and the army is something that is ready in case of danger, but you are needed every day. ${ }^{72}$

70 See 'Rules of the PRC Regarding Punishment of Counter-Revolutionaries' (21 February 1951).

71 See 'Suppression of Counter-Revolutionaries Must Implement the Party's Mass Line' (15 May 1951), Selected Works of Mao Zedong, Vol. 5, People's Publishing House, 1977, p. 40.

72 Supra note 56, p. 249. In 1990, Central Committee documents taking the Public Security's 'Half System' suggestion expanded their formulation of 'Political Legal Units as One Half of National Security' as a change in every part of political legal work. See 'Circular of the CCP Central Committee Regarding Maintaining 
Thus, at this time, the system did not lack a specialized organ to administer overall control and coordination. ${ }^{73}$ The Political Legal Committee in 1951 was only established in the internal branches of government at the provincial level and above, assisting the leaders of these government branches to manage the duties of policymaking research, drafting, enforcement, mutual relations, internal adjustment, linking up, and unification of political-legal units. Further, special districts, as well as the grassroots municipalities and counties that directly handled the vast majority of cases, did not establish political legal committees, stipulating instead that 'When special office levels in county-level people's governments have a need and the proper conditions, they can gradually establish political-legal joint offices via approval of the provincial-level people's government. ${ }^{74}$ In November 1951, when giving the Administration Council Committee's Party Leading Group Sub-Committee Report, the All-China Personnel Allocation (编制) Conference shared its opinion regarding adjusting personnel allocation and creating a joint office for the Central Political Legal Committee and the Administration Council Committee's Politics and Law Committee. The three committees - Politics, Finance, and Culture were only established in provinces (municipalities). The Political and the Culture Committees only established committees in large administrative districts and provinces (municipalities) and did not establish personnel quotas. $^{75}$

Owing to the end of the Korean War and the conclusion of policies

Social Stability and Strengthening Political Legal Work' (CCP Central Committee Doc. No. 6 [1990]), 2 April 1990.

73 Between 1949 and 1954, the authority of the internal units of the Political Legal Committee became relatively large, but afterward gradually receded - even after the 3rd National Civil Affairs Conference. Although the Internal Affairs Department (Civil Affairs Department) during this period and during 1978-1988 was reorganized as a political-legal office, it definitely did not cut into litigation structures and had little conflict with other organs. See 'Civil Affairs Department Major Events (1949-1986)', PRC Civil Affairs Department, 1988, pp. 3-89; The Editorial Department for Biographies of Contemporary Chinese Personalities, Chen Yi's Biography, Contemporary China Publishing House, 1991, pp. 277-279.

74 'Instructions of the Administration Council Committee, the Supreme People's Court, and the Supreme Procuracy Office Regarding Provincial (Municipal, Administrative Office) Level and Above People's Governments Establishing Political Legal Committees' (31 May 1951), Selected Documents on the Personnel Allocation System, Labor and Human Resources Publishing House, 1986, pp.602-603.

75 See 'To the Administration Council Committee Party Leading Group Work Team' (15 November 1951), Collected Letters of Bo Yibo, Central Party History Publishing House, 2009, pp. 237-238. 
involving land reform and the suppression of counter-revolutionaries, the entire political authority, starting from the First Five-Year Plan in 1953, entered a period of routinization. With the issuing of the 1954 Constitution, the People's Court Organization Law, the People's Procuracy Organization Law, and the Regulations on Arrest and Detention, recent Western forms and definitions of investigation, litigation, adjudication, enforcement, and forcible imprisonment, as well as the institutions for implementing litigation procedures, judicial work, and government affairs, emerged in basic form. However, this system differed from the criminal litigation established in China under the Republican era's 'Five Power Constitution,' which placed the Judicial Yuan among the five highest government powers, with the Supreme Court and the Ministry of Justice among the organs under it. In the Republican system, the Procuratorial Yuan was established within courts, and the framework by which the procuracy leads police investigation was also not the same as the British and American systems, which take courts as the entire center for advancing the litigation process and exhibit a litigation structure in which the prosecution and criminal defense confront each other. Rather, the Republican system fragmented the litigation function and allocated responsibility for investigation, arrest authorization, pre-trial, complaint, judgment, and enforcement procedures to different organs, applying the 'mutually coordinate and mutually supervise' principle between organizations. ${ }^{76}$ In this way, leadership ideology reflects the CCP Central Committee pre-Cultural Revolution basic political administrative guiding principles that were written into the CCP 8th Party Congress Political Report. ${ }^{77}$ Additionally, the organs of the justice ministry were also wedged into the litigation structure, dividing power into sections: the organs of the justice ministry at one level below possessed power in local courts over appointment and removal for Assistant Judges, and they were also responsible for judicial administrative affairs within courts; further, court personnel allocations and office organs were also regulated by the Ministry of Justice.

76 See 'Report on the Conference Regarding the Duties of the National Procuracy' (21 November 1954, Selected Documents of Peng Zhen, People's Publishing House, 1991, p.267; 'Speech at the 6th National Public Security Conference' (9 June 1954), Peng Zhen, On Political Work in New China, Central Documents Publishing House, 1992, p. 100.

77 'Our public security organs, procuracy, and courts must implement the division of labor and responsibility in the legal system, as well as a system of mutual limitations,' Liu Shaoqi, 'Political Report of the CCP Central Committee to the 8th National People's Congress,' 15 September 1956, CCP Central Committee Documents from the 8th National People's Congress, People's Publishing House, 1957, pp. 53-54. 
Inevitably, there will occur differences among branches and conflicts should different organs, during divided time periods and with divided functions, process litigation. Arrests will not be approved, additional investigations will be called back, complaints will be reversed, judgments of not guilty will be found, there will be alterations of criminal charges, and activities such as procuratorial supervision will become routine in the litigation process. But since the war era, with diversely affiliated organs mutually completing the same duty, the CCP Central Committee's basic political answer was to construct an organ that contained all of these aforementioned functions and continuously monopolized the entire situation, in unified fashion, coordinating disputing parties and realizing the central work function.

In 1942, with the North China 8th Route Army up against the Japanese Army's cruel 'War for Public Security (治安战), ' and with the New 4th Army of Central China facing the illegitimate Japanese authorities' unprecedented 'Clean the Countryside (清乡)' military action, the CCP Central Committee brought out the 'unified leadership' ideology and a major organizational adjustment response which required that 'every base of operations have one unified Party Committee that leads everything. ${ }^{77}$ In the period when the war was decided, Mao Zedong mentioned many times that 'Carrying out a large-scale war requires implementing commands with a high degree of unity, which requires construction of a unified command structure to coordinate and command every unit's war operations, as well as to take responsibility for the CCP Central Committee and the Central Military Commission. ${ }^{7}{ }^{7}$ In November 1948, during the Huaihai Campaign, the war zone's central theater (the China theater) was overseen by two field armies, the CCP Central Committee's East China Bureau, the Central Plains Bureau, the Henan-Anhui-Jiangsu sub-bureau, the local Party Committee North Jiangsu Work Committee, and the Hebei-Shandong-Henan District Party Committee. Mao Zedong radioed:

Liu Bocheng, Deng Xiaoping, Chen Yi, Su Yu, and Tan Zhenlin form the 'Plan Everything' Chief Frontline Headquarters, and five-person conferences can be for discussing important problems, and more frequently Liu, Chen, and Deng as standing members can face crucial points and handle everything, with Comrade Xiaoping as the Chief Frontline Headquarters Secretary. ${ }^{80}$

78 Supra note 6.

79 China People's Liberation Army History, Vol. 3, Military Science Publishing House, 2010, pp. 232-233.

80 'Liu, Chen, Deng, Su, Tan Form a Chief Frontline Headquarters and Plan Everything' (16 November 1948), Collected Works of Mao Zedong, Vol. 5, 
In January 1949, during the Pingjin Campaign, North China's two field armies with seven troop divisions were in the war zone's Eastern Theater, along with the CCP Central Committee North China Bureau, the Northeast Bureau, two local Pingin Municipal Committees, and two army management group organs. Mao Zedong sent an order down to set up a Pingjin Chief Frontline Headquarters: 'All military affairs, politics, finance, economics, foodstuffs, currency, foreign affairs, culture, Party affairs, and every other important work issue is placed in its jurisdiction, and this single authority helps avoid difference of opinion. Two municipal committees and two military administration groups regarding the above-described work all requested instructions from the Chief Frontline Headquarters, with the Chief Frontline Headquarters responsible directly to the Party Center ${ }^{281}$ and Lin Biao as the Chief Frontline Headquarters Secretary. In March 1949, the Jinzhong Military District local army unit had three independent brigades, the 4th field army had one artillery division, and the North China Field Army deployed the 18th, 19th, and 20th troop divisions, and the first field army's 7th unit besieged Taiyuan. On March 17, the Central Military Committee also decided to establish a Taiyuan Campaign Chief Frontline Headquarters, with unifying commands and Xu Xiangqian acting as Secretary. ${ }^{82}$ Since 1942, the structure of the Chief Frontline Headquarters has been a specific organizational expression that has continuously persisted as a 'Party Unified Leadership' ideology.

After the founding of the PRC, professional sectors, including culture and education, finance and trade, industry, agricultural industry, and politics and law, continued the tone of the war era and came to be called 'battle lines;' 'political battle lines' bore responsibility for addressing the 'unarmed enemy' in the 'national security half system,' as in the Heping era, and became considered an important domain second only to military combat. However, at the beginning of 1954, after establishing a framework for the 'mutual coordination, mutual limitation' litigation structure, the CCP Central Committee's internal system had no general committee regarding 'political legal battle lines' for overall planning and

Military Science Publishing House and Central Documents Publishing House, 1993, pp. 230-231.

${ }^{81}$ 'The Central Committee Decides Lin Biao, Luo Ronghuan, and Nie Rongzheng Will Organize a Chief Frontline Headquarters' (10 January 1949), Collected Works of Mao Zedong, Military Science Publishing House and Central Documents Publishing House, 1993, p. 479.

82 See 'War History of the China People's Liberation Army North China Field Army,' Liberation Army Publishing House, 2011, pp. 408-433. 
coordination of conflicts arising between political-legal organs. After the aforementioned Political Legal Committee was eliminated, Public Security Director Luo Ruiqing took responsibility for the State Council's First Office (Political Legal Office), which led the work of the Internal Affairs Bureau, the Ministry of Justice, and the Supervisory Office. However, regarding horizontal relations, the State Council's First Office only coordinated with the State Council's four internal offices and was not involved with the State Council's parallel political legal organs - the Supreme Court and the Supreme Procuracy Office.

Regarding vertical relations and political-legal, finance, culture and education affairs, the State Council First Office could not independently issue orders to provincial- and municipal-level Party Committees. This design is clearly expressed in the 1954 Constitution and Mao Zedong's verse, and Mao also emphasized this system in a severe reprimand of the Finance Ministry in 1955. In January 1955, the Ministry of Finance Party Leading Group, regarding the issue of a corrupt tax official stealing national funds, reported to the State Council and then to the Center in a report; at the end of the report, the Ministry of Finance requested that the State Council take this report and disseminate it to every provincial and municipal Party Committee. Regarding this situation, Mao Zedong wrote two criticisms to seven others including Liu Shaoqi and Zhou Enlai. In these criticisms he emphasized that:

This is the Ministry of Finance Party Leading Group writing to the State Council to ask it to 'disseminate a report to every provincial and municipal Party Committee.' This kind of thinking, in which the government issues orders to Party Committees is mistaken, and does not stop at one bureau. Please correct this ... Transmitting an order from the State Council to every provincial and municipal Party Committee, this method is not correct, issuing this kind of internal order makes it seem as if it is appropriate for both the State Council and the CCP Central Committee to jointly transmit orders to lower levels. ${ }^{83}$

Looking at this specific instance, it does not seem that this style of transmitting orders violates Party work style. The Ministry of Finance Party Leading Group sends forth a request to the State Council to take a report and distribute it, assuming that the State Council can distribute the order in the name of the State Council Party Leading Group to provincial

83 'Two Commentaries Regarding the Lack of Capability for a Government to Issue Internal Orders to a Party Committee' (13, 17 January 1955), Documents of Mao Zedong Since the Founding of the Country, Vol. 5, Central Documents Publishing House, 1991, pp. 7-8. 
and municipal Party Committees. On a superficial level, this is simply an instance of internal work report distribution. However, if the State Council can give orders like this to provincial and municipal-level Party Committees, then the CCP Central Committee cannot actually 'monopolize power.'

Because of this, in 1955, with the purge of counter-revolutionaries, the CCP Central Committee established a Central ten-person leading small group, and the Party Committee in every province and municipality established a five-person leading small group. But these small groups were only temporary institutions,$^{84}$ whereas the police, procuracy, courts, and Ministry of Justice - those involved with every other kind of political-legal issue - work every day; in light of the structural tensions of the system, this power necessitates a formal organ within the CCP hierarchy.

In reality, as early as 1952, as Mao Zedong and Liu Shaoqi designed the Central CCP organs other than the Central Organization Department and the Central Propaganda Department, it seemed as if they would design a political-legal work unit with Peng Zhen as Director. ${ }^{85}$ But because of the occurrence of top-level issues in 1953, the Political Legal Bureau's design was shelved, and at this time, systemic tensions became even more prominent than they were in 1952. Then, in April 1955, Liu Shaoqi revealed during a talk with provincial and municipal officials from the North China District that the CCP Central Committee was considering a new design:

The experience of the Soviet Union is that the government has one unit for professional work, and the Party Committee has a bureau to manage that unit's cadres, political-ideological work, and inspection work. The Party Committee does not directly manage professional work of the government unit, but it must still understand that unit's work, just like the politburo with respect to army units. We might have to do something like this in the future. ${ }^{86}$

In December 1955, Supreme People's Court President Dong Biwu drafted a report for the CCP Central Committee's Secretariat, which Liu Shaoqi forwarded to Mao Zedong. This report stated:

84 See 'Instructions of the Central Committee Regarding Thoroughly Purging All Counter-Revolutionary Elements in Hiding' (25 August 1955), Selected and Edited Important Documents Since the Founding of the Country, Vol. 7, Central Documents Publishing House, 1993, pp. 134-148.

85 See 'Problems Regarding Strengthening the Central Committee Work Organs' (15, 18 July 1952), Documents of Liu Shaoqi Since the Founding of the Country, Vol. 4, Central Documents Publishing House, 2005, pp. 333-337.

86 'Regarding Party Committee Leaders and Party-State Division of Labor Problems' (April 1955), Liu Shaoqi On Party Construction, Central Documents Publishing House, 1991, p. 624. 
Currently, the setup of the Political Legal organs is such that every unit's Party Leading Group is separately subordinate to the CCP Central Committee, so that every political-legal unit lacks a unified, coordinating organization. Because of this, I suggest that the CCP Central Committee establish a Politics and Law Committee or a Legal Working Group to assist the CCP Central Committee in strengthening the coordination and unified leadership of political and legal work units in state organs. ${ }^{87}$

The report also proposed that Peng Zhen or Luo Ruiqing assume authority over the committee's leadership work. The CCP Committee Secretariat and the Central Politburo approved the establishment of the CCP Central Committee Legal Committee (法律委员会), and on July 6, 1956, convened its first meeting, with Peng Zhen as Committee Director, and Dong Biwu, Public Security Bureau Director Luo Ruiqing, Supreme People's Procuracy President Zhang Dingchen, and the Ministry of Justice's Party Leading Group Vice Secretary Chen Yangshan as members. This Committee's mission was 'To research issues such as guidelines for legal work and the boundaries for the division of labor in legal work-units, as well as to handle work assigned by the CCP Central Committee.' One of the topics for discussion at the first meeting was 'The issue of inter-branch relations between the Public Security Bureau, the procuracy, the courts, and the Ministry of Justice. ${ }^{88}$ The establishment of the CCP Central Committee Legal Committee was viewed as 'an organizational way to remedy the lack of an overall plan and the coordination problems in the political legal units within national institutions.' 89

After the establishment of the CCP Central Committee, the 'Conclusions reached by the CCP Central Committee Legal Committee' regarding major work topics in the political-legal arena were released, including several criminal law policies such as 'Possible Issues Related to the Results and Necessity of the Second Suppression of Counter-revolutionaries,' plans to 'limit use of the death penalty and increase prison time (少杀长 判), plans to 'use prison more and release fewer prisoners (多留少放), and plans to 'unify offices (联合办公).' The Public Security Bureau, the Supreme People's Procuratorate, and the Supreme People's Court all specifically communicated to the CCP Central Committee Legal Committee different ways to resolve issues regarding conflicts arising in the practice of

\footnotetext{
87 The Chronicle of Dong Biwu, Central Documents Publishing House, 1991, p. 465 .

88 Supra note 29, p. 888.

89 The Chronicles of Dong Biwu (1866-1973), Central Documents Publishing House, 2006, pp.915-916.
} 
applying the law to certain situations. ${ }^{90}$ This represented the first time in the organizational history of the CCP Central Committee that the 'Party Governing Politics and Law' ideology resulted in the creation of a formal institution..$^{91}$

However, because the CCP Central Committee Legal Committee was established after the Political Legal Committee, the latter institution is often considered the precursor to the CCP Central Committee Political Legal Committee established in 1980. ${ }^{92}$ Further, between October 1949 and September 1954, documents and the speeches of leaders frequently use titles that seemingly refer to a ' $\mathrm{CCP}$ Central Committee Political Legal Committee. ${ }^{93}$ However, these titles only bear a 'family resemblance ${ }^{94}$ to each other, and they completely differ in their organizational role and position in the political system in comparison with the CCP Committee Political Legal Committee that was established under the 'Party Governing Politics and Law' ideology.

In the political language of contemporary China, only when referring

90 See 'Summary Statement of Comrade Luo Ruiqing at the National Public Security Office and Bureau Directors' Conference' (3 September 1957), section 3 of the speech, 'Six Questions of the Political Legal Organs Related to Certain Debates and Relationships,' Selected and Edited Documents of the Public Security Conference (October 1949-September 1957), edited and published by the Public Security Bureau in September 1958, pp. 543-545.

91 Through 1955, in working organs of Party Committees at the Provincial Level, many are established in similar fashion with political legal work bureaus. See Guangdong Provincial Gazette: CCP Political History Gazette, Guangdong People's Publishing House, 2001, p. 185; CCP Liaoning Provincial Political Legal Gazette (1945-1985), CCP Liaoning Provincial Party Political Committee, 1996, p. 21 .

92 Cao Siyuan believes that the CCP Central Committee Political Legal Committee established under the Administration Council Committee that was set up immediately after the founding of the country was originally designed to be temporary in nature; however, given the lack of relevant regulations in the National Constitution and the CCP Constitution, it has been maintained until the present day, and should soon be eliminated. See Cao Siyuan, The ABCs of Political Civilization - Chinese Political Reform Plan, New York, Cozy House Publisher, pp. 107-109.

93 See 'Issues Regarding Reforming Judicial Institutions and Political Legal Cadre Replenishing and Training' (24 June 1952), 'Regarding Judicial Personnel Transformation and Replenishment Problems and Giving Letters to the Central Secretariat and Liu Shaoqi' (25 June 1952), Collected Jurisprudential Works of Dong Biwu, Law Publishing House, 2001, pp.119-128, 135; Biography of Zhang Dingchui, Central Documents Publishing House, 1996, p. 430.

94 Regarding the meaning of 'family resemblance,' see Wittgenstein [UK], Philosophical Investigations, Chen Jiaying translator, Shanghai People's Publishing House, 2001, p. 49. 
to the CCP Central Committee, the CCP Politburo, the CCP Central Committee Secretariat or CCP organs and units such as the Organization Department, the Propaganda Department, the Political Legal Committee, the Foreign Affairs Office, the Party School, or the Policy Research Office can the signifier' 'Central (中央)' apply. When referring to institutions belonging to the national government, including the NPC, the State Council, the Supreme People's Court, the Supreme People's Procuracy, their formal title to the outside world does not use the title 'Central,' even though they might be called 'central government institutions.' The title 'Central Political Legal Committee' is a simplification of the title 'Political Legal Committee of the CCP Central Committee' and signifies that the institution is attached to the working structure of the CCP Central Committee.

The title of the 'Central Political Legal Committee' established in 1949 was, by contrast, a simplification of 'Central People's Government Administration Council Committee Political Legal Committee.' The 'Central' in the title of 'Central Political Legal Committee' was used to differentiate it from other political legal committees in the six large administrative regions, such as the committees labeled 'East China' and 'South Central.' Before the elimination of the Central Bureau for Large Administrative Regions and the Committee on Large Administrative Regions in 1954, the organs of large administrative regions and many of the organs of the Central Government had identical titles, ${ }^{96}$ but these were still not top-level titles for central government bureaus, nor were province-level bureaus' equivalence with central departments, municipalities' equivalence with central offices, and other titular differences used at that time to formally separate hierarchical levels. In this period, the central government internal system organs and the CCP Central Committee's structures were the same, and they were all labeled 'Central' to show their difference with bureaus and committees (e.g., the Military Political Committee) of large administrative regions, for example the Central Public Security Bureau as sub-divided into the East China Public

95 Regarding the meaning and interrelationship between the 'signifier' and 'the signified,' see Ferdinand de Saussure (Swiss), Common Linguistics Course, Gao Mingkai translator, published by the Commercial Affairs Printing House, 1980, pp. 100-116.

96 See 'Decision of the Central People's Government Regarding Altering Large Administrative Districts' People's Governments' (Military Legal Committees) Organs and Responsibilities' (passed by the Central People's Government Committee, 19th Conference, 15 November 1952), The People's Daily, 17 November 1952. 
Security Bureau and the South Central Public Security Bureau, and the Central Water Works Ministry as sub-divided into the East China Military Political Committee Water Works Ministry. The title 'Central Political Legal Committee,' distinguished that unit as an organ of nonlocal administration (e.g., a Military Political Committee). Regarding the use of the term 'Central' to draw a distinction with localities and as applied in the meaning of top levels of political authority, the term was used in the titles of the Central Legal Committee and the CCP Central Committee Political Legal Committee established in 1980 to differentiate these organs from those in 'the borderline' regions and implies leadership of the central authority. After the enactment of the 1954 Constitution, the 'Central People's Government' became an organizational title that was no longer used, and terms such as Central Public Security Bureau and Central Water Works Ministry became rarely used, while organs labeled 'Central' came to signify working branches of the CCP Central Committee.

The word 'Central' in distinguishing the objects to which it refers also renders more distinct the ideology of 'Party Governing Politics' in the process of the CCP's Organizational History. The CCP Central Committee Legal Committee's establishment employed the ideology of 'Party Committee Unified Leadership,' 'Planning Everything,' and 'General Frontline Headquarters' in political-legal work. Because the Central Political Legal Committee that was established in 1980 traces its own political and conceptual support to common origins, the 'Party Governing Politics and Law' ideology has become an important point in the CCP era.

\section{THE CENTRAL GROUP OF POLITICS AND LAW}

In the period between the enactment of the Constitution in 1954 and the 8th National Party Congress in 1956, the CCP established a stable, foundational, political-administrative framework. However, after this, the international Communist movement and China's domestic political and social development again brought about continuous changes in CCP institutional organs.

In 1957, with the Soviet Union's Communist Party acting as the 'Big Brother' to the CCP, a major political crisis occurred: from June 18 to 22, the Soviet Communist Party Presidium held a meeting, at which six members of the Presidium, including Malenkov, opposed Khrushchev's program for the period after the 20th National Soviet Party Congress; further, they decided to remove Khrushchev's position as First Secretary, with only Mikoyan, Suslov, and Kirigin supporting 
Khrushchev. However, Ministry of Defense Director Zhukov, standing at Khrushchev's side, urgently deployed a military plane, brought Soviet Central Committee members that were in other parts of the country back to Moscow, re-convened a Plenary Session of the Soviet Central Party Committee from June 22 to 29, passed a resolution 'regarding Malenkov, Kaganovich, and Molotov's anti-Party bloc,' re-convened the Presidium, and resolved the political crisis. ${ }^{97}$

For the CCP during the Red Guard period, from the resistance and the war of liberation leading the Chinese Revolution to military success and the seizure of power, to sending troops to Korea and obtaining a strategic victory, Mao Zedong several times stood his ground against mass opinion in the decisive moments of grand strategy. In the end, Mao confirmed his position through the results of his decisions, and thus acquired great prestige and self-confidence. After the completion of the 'Three Great Transformations,' Mao Zedong believed that China's reforms had already realized public ownership of the means of production and that China enjoyed a peaceful external environment. Because of this, Mao believed that the type of development in which scattered powers are assembled together to realize the 'smashing of routine' was possible. However, from 1956 to 1958, a difference of opinion regarding the planning of the economy arose between Mao Zedong and the leaders responsible for the economy, for example Zhou Enlai, Chen Yun, Li Xiannian, Deng Zihui, with both sides entering a spiral of debates and provocations - a volatile conflict that ultimately gave way to the Great Leap Forward.

The unforeseen event that had occurred in the Soviet Union, which possessed identical political structures to China, as well as China's domestic situation, compelled Mao and the CCP Central Committee to make new deployments. From the 1956 conference at Beidaihe, which was attended by tens of people, Mao mentioned the possibility that he might no longer assume the national chairmanship. In April and May 1957 and then in 1958, Mao again mentioned several times the prospect of his resigning as Chairman at the 2nd National Party Congress in 1959 'to concentrate his energy on researching some important questions. ${ }^{98}$ In the aftermath

97 See 'Decision of the Soviet Central Party Committee Plenary Session Regarding Malenkov, Kaganovich, and Molotov's Anti-Party Bloc,' in The Soviet Union Communist Party's Final 'Anti-Party' Bloc, Zhao Yongmu et al., translator, China Society Publishing House, 1997, pp.973-981; The Un-amended Record, Zhang Junxiang and Shi Guoxiong, translators, Translated Works Publishing House, 2009, pp.455-470.

98 'Commentary Regarding No Longer Serving as National Chairman' (5 May 1957), Documents of Mao Zedong Since the Founding of the Country, Vol. 
of the airing of differences of opinion among several other leaders in the government, Mao Zedong became determined to accelerate and advance the adjustment of 'Party-State' administrative organs, transforming this organizational line into the political line at the 2nd Plenary Session of the 8th Party Congress.

Mao Zedong's style of choice was to give the 'monopoly of power' to the Central Politburo and the Central Politiburo-controlled Central Secretariat. In January 1958, at the Nanning Conference, Mao Zedong, taking a swipe at the political-legal organs, again mentioned 'the 8 Line Rhyme,' emphasizing the Central Committee's consolidated leadership:

The Political Legal organs have some who are saying that the Party and State aren't separate, shouldn't it be that each takes half? That isn't right, do not start out separate, but rather separation can be done later - or else it'll just be a monopoly on small power ... small power, small portions. Big power can’t be monopolized. ${ }^{99}$

Afterward, the work content and the work forms of the CCP Central Committee Secretariat underwent adjustment. In February 1958, Mao Zedong proposed that the CCP Central Secretariat should bring the work of the State Council and every bureau and committee under control, and Zhou Enlai proposed establishing five groups united under the Party-State. ${ }^{100}$ Immediately afterward, in May 1958, at the 5th Plenary Session of the 8th Party Congress, Lin Biao was added as CCP Central Committee Vice Chairman and Politburo Standing Committee Member. Mao Zedong's trusted confidants Ke Qingshi, Li Jingquan, and Tan Zhenlin were also added as Central Politburo members, and Li Fuchun and Li Xiannian became Secretaries in the Central Secretariat, 'in order to take some of the problems in the State Council and its internal bureaus and bring them to the Secretariat for discussion.' ${ }^{101}$

In June 1958, after re-constituting the membership of the Politburo Standing Committee, the Politburo, and the Secretariat, the CCP Central

6, Central Documents Publishing House, 1992, pp.457-461; see also 'Sixty Rules for Work Methods (Draft)' (January 1958) and 'Transmission to Huan Xiang Regarding Revealing Mao Zedong's Preparations to Resign as National Chairman' (31 July 1958), Documents of Mao Zedong Since the Founding of the Country, Vol. 7, Central Documents Publishing House, pp. 64, 332-333.

99 'Speech at the Nanning Conference' (January 1958), Long Live Mao

Zedong Thought, published by Yi Ming, 1969, p. 148 (emphasis added).

100 See Biography of Peng Zhen, Vol. 3, Central Documents Publishing House, 2012, p. 966.

101 Supra note 27, p. 438. 
Committee decided to establish Small Groups in Finance, Politics and Law, relying on a proposal drafted by Zhou Enlai. Mao Zedong added to the notice announcing the proposal a large comment and correction regarding the 'division of authority,' which reiterated the 'unified' line of administrative thought used since 1942, and responded to the previous year's opinion of China Democratic League Central Vice Chair Zhang Bojun's 'Four Institutions of Political Design': 102

These CCP Central Committee small groups belong directly to the Central Politburo and Secretariat and do reports directly for them. Fundamental guidelines are in the Politburo, specific deployments in the Secretariat. There can only be an 'Institution of Political Design,' not two 'Institutions of Political Design'. Fundamental guidelines and specific deployments are all unified, and the Party-State is not divided. Specific enforcement and detailed decisionmaking belong to governmental organs and their Party Leading Groups. Regarding fundamental guidelines and specific deployments, governmental organs and Party Leading Groups have authority to make suggestions, but decision-making power belongs to the CCP Central Committee. Governmental organs, Party Leading Groups, and the CCP Central Committee together have the authority to inspect. The consolidation of authority is in the Standing Committee and in the Secretariat. I am the commander-in-chief, and Deng is second-in-command. ${ }^{103}$

The Leader of the newly established Central Group of Politics and Law was Peng Zhen, who at the time also served as a member of the 8th Politburo and as the Central Secretariat Standing Secretary assisting General Secretary Deng Xiaoping in his general responsibilities. Peng also was in charge of the United Front, Politics and Law, and Hong Kong and Macao work. ${ }^{104}$ Regarding the four group members, Dong Biwu was a Politburo member and the Supreme People's Court President, Wulanfu

102 Zhang Bojun said, 'Currently, industry has many planning institutes, but regarding the many political set-ups, there are no planning institutes. I see the Consultative Conference, the National Congress, the democratic parties, citizens' groups, so there should be four planning institutes for politics.' 'Boldly Launch Criticism and Fiercely Conduct Debates, the United Front Work Department Invites Democratic Party and Unaffiliated Party Types to Continue Conferencing,' The People's Daily, 22 May 1957.

103 'Commentary and Amendments Regarding Notice of Central Committee Decisions to Establish Finance, Political Legal, External Affairs, Science, Culture and Education Small Groups' (8 June 1958), Documents of Mao Zedong Since the Founding of the Country, Vol. 7, Central Documents Publishing House, 1992, pp. 268-269.

104 See Tian Youru et al., Bibliographic Sketch of Peng Zhen, People's Publishing House 2007, p. 219. 
was an alternate member of the Politburo and State Council Vice Premier, Luo Ruiqing was the Director of the Public Security Bureau, and Zhang Dingcheng was the Supreme People's Procuracy President.

From the CCP Central Committee Legal Committee of July 1956 until the June 1958 Central Group of Politics and Law, the committee head and Leader was Central Politburo Member and Secretariat Secretary Peng Zhen. However, an analysis of organizational levels indicates that, through regulatory style, the Central Group of Politics and Law became directly attached to the Central Politburo and Secretariat, dispelling the role of personality that had become a strong element of institutional change. ${ }^{105}$

Further, the Central Group of Politics and Law directly provided reports to the Central Politburo and Secretariat, rendering the CCP Central Committee more familiar with leaders' handling of political and legal affairs. According to the 8th Party Congress' amendments to the CCP Constitution, 'The Central Secretariat, under the leadership of the Central Politburo and its Standing Committee, conducts the everyday work of the CCP Central Committee.' In September 1956, during the period of the 8th Party Congress, during one of the Politburo Standing Committee meetings, Mao Zedong said to General Secretary Deng Xiaoping: 'We are doctors, the Secretariat are the nurses, you are the head nurse.' 106 According to 8th Party Congress Secretariat Secretary Li Xuefeng's memory, when the CCP Central Committee decided that Deng Xiaoping would be the General Secretary of the Secretariat, Deng mentioned to Chairman Mao that the Secretariat was still acting as an organ handling the Politburo's affairs, as a special unit in charge of Party work, and only had responsibility over delivering army and State Council documents. Mao Zedong disagreed, and emphasized to Deng that the Secretariat is the CCP Central Committee organ that gets things done, that everything needs someone to manage it, that the CCP Central Committee's affairs are the Secretariat's work, that the Secretariat handles comprehensive work, and that documents are sent in the name of the CCP Central Committee. ${ }^{107}$

105 On 8 May 1959, the Leader of the Central Group of Politics and Law was changed to State Council Vice Premier and Public Security Bureau Director Luo Ruiqing. After the Lushan Conference, Luo Ruiqing became the General Chief of Staff, and Xie Fuzhi became the Director of the Public Security Bureau, and from December 1960 through the beginning of the Cultural Revolution, he also served as the Leader of the Central Group of Politics and Law.

106 Liu Zhende, I Was Shaoqi's Secretary, Supplement, Central Documents Publishing House, 2003, p. 42.

107 See Li Xuefeng, 'My 24 Years Under the Leadership of Comrade Xiaoping,' Party Documents, 1998, Issue 3, p. 36. 
In this way, as stated above, after October 1954, every government bureau and committee corresponded with a State Council office: a first office for politics and law, a second office for culture and education, a third office for heavy industry, a fourth office for light industry, a fifth office for finance, treasury, and trade, a sixth office for transportation, a seventh office for agriculture, forestry, and water works, and an eighth office for socialist transformation of capitalist industry and commerce. Afterward, every office again was divided according to which CCP Central Committee bureau was in charge of it: the third and fourth office corresponded with the Central Industry Work Bureau, ${ }^{108}$ the second office corresponded with the Central Propaganda Department, the fifth office corresponded with the Central Finance and Trade Work Bureau, the seventh office corresponded with the Central Agricultural Work Bureau, and the eighth office corresponded with the Central United Front Bureau. ${ }^{109}$

After the establishment of five Small Groups in areas such as finance, politics and law, foreign affairs, science, culture and education, the strongest important authority was that of the CCP Central Committee leader. In the political-legal domain, political legal affairs work in the government's internal sequence was coordinated by the first office (the State Council Political Legal Office), and above the first office with the Supreme People's

108 In November 1956, the Central Transportation Ministry was divided into the Central Industrial Work Ministry and the Central Transportation Work Ministry.

109 Li Xuefeng's memory was that in the second half of 1954, the Central Committee Secretary established four offices under its authority, and the first office was to manage political legal work, with Peng Zhen as Director and Luo Ruiqing as Vice Director. See Li Xuefeng, 'Selected Recollections Regarding the Convening of the 8th Party Congress,' CCP Historical Research, Vol. 4, 1996, p. 8. However, this recollection constitutes the only evidence available, absent stronger supporting documents. Regarding the Central Secretariat's first office, there are several documents that corroborate each other: according to the determination of January 1955 Central General Secretary Conference, the Central Secretariat's first office was established from personnel promoted from the first office of the Central General Office, with no change in responsibility, and still maintaining responsibility for reading all provincial and/or municipal communication materials in documentary and electronic form, for attending every important provincial and/or municipal conference, and for providing simple reports and opinions to the Central Committee, under the authority of Central General Office Director Yang Shangkun. See The Chronicle of Deng Xiao Ping (1904-1974), Central Documents Publishing House, 2009, pp. 1208, 1211; supra note 85, p. 334; Su Wei Min, 'Yang Shangkun Discusses 20 Years in the Central General Office,' Bainian Chao, 2008, Issue 7, pp. 18-19. 
Court, the Supreme People's Procuratorate was the Central Group of Politics and Law, which directly belonged to the Central Secretariat and the Central Politburo. In this framework, Deng Xiaoping ran the Central Secretariat as second-in-command, and Mao Zedong served as General Chairman in charge of the Central Politburo and as first-in-command, leading Mao Zedong to believe that any fragmentation that had already been produced and that could be produced was eliminated, strengthening the CCP Central Committee's unified leadership over every unit's work.

After 1978, having experienced the major transformations of 1959-1961 in the political legal system and the Cultural Revolution period's broken police, procuracy, and court systems, the political-legal organs were gradually developed or recovered. In January 1980, the CCP Central Committee decided to establish a CCP Central Committee Political Legal Committee run by Peng Zhen. In February 1980, at the 5th Plenary Session of the 11th Party Congress, the CCP 'decided to recover the Party system that was decided by the 8th National Congress to be, and within ten years proved to be, both necessary and useful, and establish a frequently working organ of the Central Secretariat under the leadership of the Central Politburo and its Standing Committee.' 110 This 'Party Governing Politics' system design, which was completed in 1958 after experiencing the turmoil of the Cultural Revolution, has continued to last up to the administration seen in contemporary China. ${ }^{111}$

\section{CONCLUSION}

Since the late Qing era, that which the West has transported and which has brought great change to China has not been railroads, telephone, the Maxim gun, or the steam engine; rather, it is the Bolshevik organizational form. Mao Zedong noted: 'Thank Marx, Engels, Lenin, and Stalin. They gave us weapons - not machine guns, but Marxism-Leninism.' ${ }^{112}$

Leninism opposes the independence of fragmentation, uncoordinated progression, disunity, everyone-for-themselves, and self-emphasis. Only under bureaus and mid-level administration can there be appropriate construction of mechanisms for the distribution of power. However, the objective is only to prevent the concealment of information or some

110 'Report on the 5th Plenary Session of the 11th Party Congress (passed on 29 February 1980),' The People's Daily, 1 March 1980.

111 Regarding the CCP Central Committee Political Legal Committee's specific authority prior to this major transformation, another article is planned.

112 Supra note 20, p. 282. 
individual becoming disproportionately large in stature, or to prevent the top-most layers from losing their practical nature or their ability to promptly make political decisions. At the top-most layers, there is a need for an ultimate decision maker, and from this decision maker, coordination can be synthesized, every side can be unified, and to the greatest degree business costs can be conserved and the maximum governmental efficacy can be realized.

The Criminal Procedure Law, through the separation of functions, division of sections, and mutual tension, assigns litigation responsibility to the police, procuracy, courts, and justice ministry: the police are responsible for the investigation of ordinary criminal cases, the procuracy authorizes arrest, the police handle the pre-trial phase, and the procuracy files the complaint. At the same time, the procuracy can also perform supervision over the activities of the police, courts, and justice ministry, and through this function, crimes are investigated. Between 1954 and 1959 , local courts' judicial assistants were appointed and removed by the higher level justice ministry, the set-up of local courts was approved by the justice ministry, every level courts' administrative work was managed by the justice ministry, and court personnel allocations and bureaucratic structures were regulated by the justice ministry. ${ }^{113}$ In Leninist political thought, it is inevitable that this set-up will fail to produce cooperation, as a higher-level organ is necessary to assume general authority and coordinate all sides.

In Anglo-Saxon liberal political design, the political system does not possess final authority to exercise power or to prevent some authority from harming the political system. All authority must be intertwined and mutually restricted, with checks and balances, and no particular authority can become too prominent. Regarding justice for all those under criminal control and due process requirements, power over the litigation process from investigation to complaint and judgment should be distributed as much as possible among the police, the prosecutor, and the judge. Additionally, in all parts of litigation, lawyers should participate, and in the investigation process, ordinary citizens should be included to act as justices of the peace. The complaint period should include ordinary citizens in a grand jury; in judging guilt, ordinary citizens should form a petit jury, fragmenting the power of final judgment over a suspect or defendant.

Aristotle said: 'Wood cannot itself become a bed, bronze cannot itself become a statue. The cause of such evolution in form demands some

113 See Articles 2, 14, 34, 40 of the Law on the Organization of Courts, 1954. 
other material thing. ${ }^{114}$ The aforementioned two types of judicial administration are different, and these differences come from different political paradigms. Through Western definitional standards, the state is an organization that possesses the legitimate monopoly of violence and taxation in a given territory. ${ }^{115}$ But in the administrative system of a Leninist PartyState, the core of a state's monopoly of violence is defined by the concepts 'Party governing the military' and 'Party governing politics and law.'

114 Aristotle, Metaphysics, Wu Shoupeng, translator, Commercial Printing House, 1959, pp. 5-6.

115 Anthony Giddens, The Nation-State and Violence, Hu Zongze, Zhao Litao, translators, Life, Reading, New Knowledge Union Bookstore, 1998, p. 147; Max Weber, Sociology and Fundamental Concepts, Hu Jingbei, translator, Shanghai People's Publishing House, 2000, p.90; Reinhardt Bendix, A Portrait of Max Weber's Thought, Liu Beicheng et al., translators, Shanghai People's Publishing House, 2002, p. 409. 